\title{
Chediak-Higashi Syndrome: Abnormal Lysosomal Enzyme Levels in Granulocytes of Patients and Family Members
}

\author{
TAKEO TANAKA ${ }^{(24)}$ \\ Department of Pediatrics, Hiroshima University School of Medicine, 1-2-3, Kasumi-cho, Hiroshima, 734, Japan
}

\begin{abstract}
Summary
Nine lysosomal enzyme activities were examined in granulocytes and lymphocytes from two unrelated patients with Chediak-Higashi syndrome (CHS) in "accelerated phase" and from their family members. In CHS granulocytes, there was a marked reduction of $\alpha$-mannosidase (E.C. 3.2.1.24), $\alpha$-galactosidase (E.C. 3.2.1.22), and $\alpha$-fucosidase (E.C. 3.2.1.51) activities, which were below 21,24 , and $43 \%$ of mean control values, respectively. In CHS lymphocytes, $\beta$-glucuronidase (E.C. 3.2.1.31) and $\alpha$-mannosidase activities were also decreased.

In granulocytes of family members, the activities of acid phosphatase (E.C. 3.1.3.2), $\boldsymbol{N}$-acetyl- $\boldsymbol{\beta}$-glucosaminidase (E.C. 3.2.1.30), aryl sulphatase (E.C. 3.1.6.1), and $\beta$-glucuronidase were significantly higher than the control values $(P<0.001)$, which were 262 , 218,414 , and $180 \%$ of mean control values.

Neither the inhibitor in CHS granulocytes nor the activator in the heterozygous granulocytes to those enzymes could be found by mixing experiments with normal ones.

\section{Speculation}

These findings suggest that some acid hydrolase-deficient state in CHS granulocytes might account for their functional abnormality and that CHS heterozygotes could be detected by the altered enzyme levels in their granulocytes.
\end{abstract}

The Chediak-Higashi syndrome (CHS) is a rare autosomal recessive disorder characterized by partial oculocutaneous albinism and abnormally large granules in all granule-containing cells. A major clinical manifestation of this disease in affected patients is the occurrence of multiple bacterial infections. The majority of patients succumb at an early age, usually from recurrent pyogenic infections. Some patients develop lymphoreticular infiltration in liver, spleen, lymph nodes, and bone marrow with many similarities to malignant lymphoma. which now is called "accelerated phase" $(4,21)$.

The hallmark of CHS is the presence of the large azurophilicstaining granules. Histochemical studies have shown that the giant granules contain acid phosphatase and peroxidase. Therefore, it has been postulated that CHS may represent an example of a "lysosomal disease" (19). However, the relationship of the genetic defect to the morphologic findings and the predisposition to pyogenic infections has yet not been elucidated $(10,14,21)$.

The investigations of this syndrome and the nature of the heterozygous state have been limited by the paucity of affected individuals. There are few descriptions and contradictory reports concerning the biochemical properties of lysosomal enzymes in CHS leukocytes $(9,11,15)$. Many lysosomal enzymes have yet to be studied.

For determinating the levels of lysosomal enzymes in CHS leukocytes, we examined the biochemical activities of nine lysosomal enzymes in the peripheral granulocytes and lymphocytes of unrelated two patients in accelerated phase and also of their family members. We describe here the abnormalities of these lysosomal enzyme activities in the granulocytes of CHS patients and obligated heterozygotes; these have not been reported to date.

\section{CASE REPORT}

Case 1 (Y.K.) was a 4-month-old girl. She was the third child of nonconsanguineous parents. The first child was a healthy 5year-old boy, and the second was a female who had died of pneumonia at 3 months of age. Febrile episodes in this patient began at $1 \frac{1}{2}$ months of age. At 2 months of age, she was referred to Himeji Red Cross Hospital for the evaluation of cervical lymph node swelling and hepatosplenomegaly. She was diagnosed as having CHS on the basis of the characteristic partial albinism and typical abnormal granules in the leukocytes of the peripheral blood and bone marrow. At 3 months of age, she began to have anemia, thrombocytopenia, and jaundice, in addition to neutropenia and hepatosplenomegaly. Vitamin $\mathrm{C}$ and antibiotics were attempted with no effects. She was then transferred to our department for the treatment and further evaluation of CHS. On admission, she was interpreted to be in accelerated phase. The therapy with glucocorticoid hormone and vincristine was begun. The response to this therapy was prompt and followed a good clinical course.

Case 2 (K. S.) was a 3-yr-old boy, not related to Case 1. The parents were nonconsanguineous. He had frequent febrile episodes starting at 6 months of age, which were controlled by antibiotics without deterioration. He was referred to Osaka Red Cross Hospital at $3 \mathrm{yr}$ of age for further evaluation of frequent infections and hepatosplenomegaly. He had typical manifestations of CHS After admission, he was treated with vitamin $C$ and antibiotics. However, at $3 \frac{1}{12}$ yr of age, fever became unresponsive to antibiotics. Therapy with vincristine and glucocorticoid hormone was begun for the accelarated phase. Vincristine was discontinued when the neuritis and motor disturbance developed. Then alternative therapy was maintained with steroid hormone, methotrexate, and cyclophosphamide.

Although the two cases maintained improving clinical course after begining above mentioned therapy for accelerated phase, the therapy became gradually uneffective. Both Cases 1 and 2 died of accelerated phase at $14 / 12$ years of age and $4 \mathrm{yr}$ of age, respectively.

\section{MATERIALS AND METHODS}

\section{PREPARATION OF LYMPHOCYTES AND GRANULOCYTES FOR THE} ENZYME ASSAY

The leukocytes for lysosomal enzyme assay were prepared from Case 1 just before the initiation of the treatment for the accelerated 
phase (4 months of age) and from Case 2 under treatment for the accelerated phase $(3 \% / 12$ yr of age). The parents of both patients and a brother of Case 1 had no symptoms of any disease when the enzyme activities in the leukocytes were examined.

Peripheral blood leukocytes were separated into two fractions, mononuclear cells and erythrocyte-containing granulocytes, by means of sodium metrizoate-Ficoll gradients (5). The lymphocytes were prepared from the former by removing monocytes with carbonyl iron (18). The granulocytes were obtained from the latter fraction by dextran sedimentation followed by hypotonic lysis. The cell population in each fraction was examined in Wrightstaining smears. Contaminating monocytes were examined by nonspecific esterase staining (22). The purity of prepared granulocytes and lymphocytes was over $98 \%$. The contaminating monocytes in the lymphocyte fractions were 0.6 to $1.2 \%$. The morphologic abnormality was not found in the cells from the family members.

The cells were homogenized in an ice-melting bath with $3 \mathrm{ml}$ of $0.1 \%$ Triton X-100 solution for a hundred strokes in a Dounce homogenizer. The cell homogenate was then briefly sonicated ( 9 $\mathrm{KHz} ; 3 \mathrm{~min}$ ) following centrifugation at $450 \times \mathrm{g}$ for $10 \mathrm{~min}$. The supernatant was used as a cell lysate.

\section{DETERMINATION OF NINE LYSOSOMAL ENZYME ACTIVITIES}

The conditions for measurement of enzyme activities have been reported previously $(16,17)$. The amounts of enzyme activity in the cell lysates were determined with 4-methylumbelliferyl (4MU) compounds (Koch-Light Labs. Ltd., Buckinghamshire England) in the following manner for the optimal condition. Substrates in $0.2 \mathrm{M}$ acetate buffer solution were: acid phosphatase $(0.2 \mathrm{mM}$ 4MU-phosphate, pH 5.0), $N$-acetyl- $\beta$-glucosaminidase $(0.2 \mathrm{mM}$ 4MU- $N$-acetyl- $\beta$-D-glucopyranoside, pH 6.0), $\beta$-glucuronidase ( $0.2 \mathrm{mM} 4 \mathrm{MU}-\beta$-D-glucuronide, $\mathrm{pH} 3.5$ ), $\beta$-galactosidase $(0.2 \mathrm{mM}$ $4 \mathrm{MU}-\beta$-D-galactopyranoside, $\mathrm{pH} 4.0), \alpha$-mannosidase $(0.2 \mathrm{mM}$ 4MU- $\alpha$-D-mannopyranoside, $\mathrm{pH} 4.5), \alpha$-fucosidase $(0.2 \mathrm{mM}$ 4MU- $\alpha$-L-fucopyranoside, $\mathrm{pH} 5.5), \alpha$-galactosidase $(2.0 \mathrm{mM}$ $4 \mathrm{MU}-\alpha$-D-fucopyranoside, $\mathrm{pH} 4.5$ ), $\beta$-fucosidase $(2.0 \mathrm{mM} 4 \mathrm{MU}$ $\beta$-D-fucopyranoside, $\mathrm{pH} 4.5)$, and aryl sulphatase $(2.0 \mathrm{mM} 4 \mathrm{MU}$ sulphate $\mathrm{K}$ with $0.1 \mathrm{M} \mathrm{NaCl}$, pH 5.0). Aliquots of $100 \mu \mathrm{l}$ each of buffered substrate solution and cell lysate ( 50 to $80 \mu \mathrm{g}$ protein per $100 \mu \mathrm{l}$ ) were mixed and incubated at $37^{\circ} \mathrm{C}$ for $30 \mathrm{~min}$, except for aryl sulphatase and $\beta$-fucosidase, which were incubated for $4 \mathrm{hr}$. The reaction was terminated by the addition of $3.3 \mathrm{ml}$ of $50 \mathrm{mM}$ glycine- $\mathrm{NaOH}$ buffer ( $\mathrm{pH}$ 10.4) containing $5 \mathrm{mM}$ EDTA. Fluorescence was measured in a Hitachi Fluorescence Spectrophotometer (204-R) at an excitation wavelength of $365 \mathrm{~nm}$ and an emission wavelength of $450 \mathrm{~nm}$. The enzyme activity was expressed as pmoles of substrate hydrolized per min per $\mu \mathrm{g}$ DNA in lysate. As we reported, the activity based on DNA showed a good correlation with that expressed by cellular basis $(16,17)$. DNA was determined by the method of Hinegardner (8).

\section{RESULTS}

\section{LYSOSOMAL ENZYME ACTIVITIES IN GRANULOCYTES AND} LYMPHOCYTES OF CHS PATIENTS

As shown in Table 1 , there was a marked reduction of $\alpha$ mannosidase, $\alpha$-galactosidase, and $\alpha$-fucosidase activities in granulocytes below 21,24 , and $43 \%$ of mean control values, respectively. The $\beta$-glucuronidase activity of case 1 was near the lower limit of the control value, and $N$-acetyl- $\beta$-glucosaminidase of case 2 and $\beta$-fucosidase of case 1 were above the normal range (mean +2 S.D.). In our studies, there was no difference in these enzyme activities in granulocytes between normal adults and children; for example, in children from 3 months to one yr of age, $\alpha$-mannosidase, $\alpha$-fucosidase, and $\beta$-glucuronidase activities in granulocytes were $24 \pm 9,21 \pm 6$, and $55 \pm 15$ pmoles of substrate hydrolyzed per min per $\mu \mathrm{g}$ DNA, respectively.

In CHS lymphocytes (Table 2), the activity of $\beta$-glucuronidase and $\alpha$-mannosidase was also decreased in both cases. The activity of $\beta$-galactosidase in case 1 and $\alpha$-galactosidase in case 2 showed low values. The others were within the normal range, except for high aryl sulphatase activity in case 2.

\section{LYSOSOMAL ENZYME ACTIVITIES IN GRANULOCYTES AND} LYMPHOCYTES OF FAMILY MEMBERS

In granulocytes from the parents of both cases (Table 1), there was a marked elevation of the following lysosomal enzyme activities: acid phosphatase, $N$-acetyl- $\beta$-glucosaminidase, and aryl sulphatase. $\beta$-Glucuronidase activity was also high in both fathers and in the mother of Case 2 , and $\alpha$-galactosidase activity was elevated in both fathers. The activities of the remaining four enzymes showed no significant changes. The brother of case 1 had a similar profile of the nine enzyme activities in the granulocytes to that of the obligate heterozygotes (the parents); i.e., high acid phosphatase, $N$-acetyl- $\beta$-glucosaminidase, aryl sulphatase, and $\beta$-glucuronidase activities, which may suggest that he is a heterozygote of CHS. When the mean activities of these enzymes in CHS heterozygotes including the brother of case I were compared with those of normal controls, the high activities of acid phosphatase $(262 \%), \beta$-glucuronidase (180\%), $N$-acetyl- $\beta$-glucosaminidase $(218 \%)$, and aryl sulphatase $(414 \%)$ were significant $(P<0.001)$, as shown in Table 1 .

In the lymphocytes of the family members, there were no significant changes of the enzyme levels (Table 2).

\section{EXAMINATION OF ENZYME INHIBITOR IN CHS GRANULOCYTES} AND THE ACTIVATOR IN THE HETEROZYGOUS GRANULOCYTES

Mixing experiments between cell lysates of patients and normal ones were performed to examine the enzyme inhibitor. The measured activities of $\alpha$-mannosidase, $\alpha$-fucosidase, and $\alpha$-galactosidase were $101 \pm 4,92 \pm 4$, and $99 \pm 3 \%$ (S.D.) of expective activities, respectively. The measured activities of acid phosphatase, $N$-acetyl- $\beta$-glucosaminidase, $\beta$-glucuronidase, and aryl sulphatase by the mixing study between normal and heterozygous cell lysates were $102 \pm 4,98 \pm 4,95 \pm 2$, and $98 \pm 7 \%$ of expective ones, respectively. These findings suggested that the abnormal levels of lysosomal enzyme activities in CHS and heterozygous granulocytes were due to neither enzyme inhibitor nor activator.

\section{DISCUSSION}

It has been thought that CHS granules result from a process of unregulated lysosomal fusion. Rausch et al. (13) reported that the abnormal granules in CHS neutrophils are formed by the progressive aggregation and fusion of normal azurophilic and specific granules and that this process occurs concurrently with normal granule formations which progressively reduces normal granules. In addition to the change of leukocyte cellular cytoarchitecture, the cytologic defect in CHS, including lysosomes, might be occurring. However, its precise nature and/or its functional significance has not been established.

This investigation was undertaken to determine the levels of lysosomal enzyme activities in CHS because there have been contradictory reports concerning the enzyme levels in CHS leukocytes. Padgett (11) found no significant differences in the amount of acid phosphatase (to $\beta$-glycerophosphate), $\beta$-glucuronidase, cathepsin, and bactericidal cationic proteins in peritoneal neutrophils from CHS and non-CHS mink and cattle. Stossel $e t$ al. (15) showed that acid phosphatase, $\beta$-glucuronidase, and peroxidase activities assayed in whole homogenates of granulocytes of CHS patients were normal, although $\beta$-glucuronidase and peroxidase activities in the granules obtained by subfractionation of CHS leukocytes were 56 to $67 \%$ of normal. Kimball et al. (9) reported that specific activities of acid phosphatase (to $p$-nitrophenyl phosphate), $\beta$-glucuronidase, and myeloperoxidase in granulocyte lysate were lower than normal, whereas acid phosphatase (to $\beta$-glycerophosphate) activity was normal and that there was a difference of intracellular distribution of activities for several hydrolases in CHS granulocytes. 
Table 1. Lysosomal enzyme activities in granulocytes of Chediak-Higashi syndrome $e^{1}$

\begin{tabular}{|c|c|c|c|c|c|c|c|c|c|c|}
\hline & \multicolumn{2}{|c|}{ Patient } & \multicolumn{4}{|c|}{ Family of Case 1} & \multicolumn{2}{|c|}{ Family of Case 2} & \multirow{2}{*}{ Heterozygote } & \multirow{2}{*}{$\begin{array}{r}\text { Control } \\
(n=14)\end{array}$} \\
\hline & Case 1 & Case 2 & & & Mother & Brother & Father & Mother & & \\
\hline Acid phosphatase & 265 & 239 & 644 & 552 & 407 & 388 & 638 & 578 & $535 \pm 112^{2,3}$ & $204 \pm 66$ \\
\hline$\beta$-Glucuronidase & 28 & 41 & 108 & 93 & 77 & 90 & 105 & 106 & $97 \pm 12^{2}$ & $54 \pm 15$ \\
\hline $\begin{array}{l}\mathrm{N} \text {-acetyl- } \beta \text { - } \\
\text { glucosaminidase }\end{array}$ & 26 & 34 & 37 & 34 & 42 & 34 & 38 & 39 & $37 \pm 3^{2}$ & $17 \pm 8$ \\
\hline$\alpha-G$ alactosidase & 2.2 & 3.1 & 21 & 24 & 17 & 18 & 27 & 11 & $20 \pm 6^{4}$ & $13 \pm 4$ \\
\hline$\beta$-Galactosidase & 5.0 & 16 & 27 & 28 & 24 & 18 & 31 & 30 & $26 \pm 5$ & $19 \pm 6$ \\
\hline$\alpha$-Mannosidase & 6.0 & 3.0 & 37 & 40 & 38 & 42 & 38 & 34 & $38 \pm 3$ & $29 \pm 9$ \\
\hline$\alpha$-Fucosidase & 9.4 & 12 & 29 & & 15 & 30 & 33 & 32 & $28 \pm 7$ & $28 \pm 4$ \\
\hline$\beta$-Fucosidase & 4.0 & 0.9 & 1.7 & 1.9 & 1.2 & 1.1 & 1.6 & 1.4 & $1.5 \pm 0.3$ & $1.1 \pm 0.3$ \\
\hline Aryl sulphatase & 2.5 & 2.9 & 6.3 & 4.4 & 3.5 & 7.0 & 6.9 & 6.6 & $5.8 \pm 1.5^{2}$ & $1.4 \pm 0.9$ \\
\hline
\end{tabular}

' Enzyme activity is expressed as pmoles of substrate hydrolyzed per min per $\mu \mathrm{g}$ DNA.

${ }^{2}$ Significantly higher at the level of $P<0.001$.

${ }^{3}$ Mean \pm S.D.

4 Significantly higher at the level of $P<0.01$.

Table 2. Lysosomal enzyme activities in lymphocytes of Chediak-Higashi syndrome ${ }^{1}$

\begin{tabular}{|c|c|c|c|c|c|c|c|c|c|c|}
\hline & \multicolumn{2}{|c|}{ Patient } & \multicolumn{4}{|c|}{ Family of Case 1} & \multicolumn{2}{|c|}{ Family of Case 2} & \multirow{2}{*}{ Heterozygote } & \multirow{2}{*}{$\begin{array}{l}\text { Control } \\
(n=6)\end{array}$} \\
\hline & Case 1 & Case 2 & & & Mother & Brother & Father & Mother & & \\
\hline Acid phosphatase & 102 & 82 & 207 & 181 & 162 & 126 & 65 & 61 & $133 \pm 61^{2}$ & $214 \pm 87$ \\
\hline$\beta$-Glucuronidase & 10 & 26 & 59 & 42 & 30 & 22 & 63 & 39 & $42 \pm 17$ & $51 \pm 12$ \\
\hline $\begin{array}{l}\text { N-Acetyl- } \beta \text { - } \\
\text { glucosaminidase }\end{array}$ & 28 & 28 & 38 & 31 & 22 & 24 & 31 & 20 & $28 \pm 7$ & $30 \pm 11$ \\
\hline$\alpha$-Galactosidase & 4.1 & 2.3 & 6.7 & 6.6 & 6.3 & 4.2 & 3.2 & 3.4 & $5.1 \pm 1.6$ & $7.2 \pm 2.3$ \\
\hline$\beta$-Galactosidase & 10 & 18 & 27 & 25 & 13 & 10 & 22 & 19 & $19 \pm 7$ & $29 \pm 9$ \\
\hline$\alpha$-Mannosidase & 1.0 & 1.0 & 3.0 & 4.0 & 3.0 & 3.4 & 3.0 & 3.0 & $3.2 \pm 0.4$ & $3.2 \pm 0.6$ \\
\hline$\alpha$-Fucosidase & 13 & 13 & 21 & & 12 & 14 & 13 & 11 & $14 \pm 4$ & $17 \pm 2$ \\
\hline$\beta$-Fucosidase & 0.7 & 0.9 & 1.7 & 1.5 & 0.9 & 0.7 & 1.4 & 1.1 & $1.2 \pm 0.4$ & $1.5 \pm 0.3$ \\
\hline Aryl sulphatase & 0.7 & 2.1 & 1.1 & 1.1 & 1.0 & 0.7 & 1.5 & 1.6 & $1.2 \pm 0.3$ & $0.9 \pm 0.2$ \\
\hline
\end{tabular}

${ }^{1}$ Enzyme activity is expressed as pmoles of substrate hydrolyzed per min per $\mu \mathrm{g}$ DNA.

${ }^{2}$ Mean \pm S.D.

In this study, acid phosphatase (to 4MU-phosphate) activity in CHS granulocytes was normal, and $\beta$-glucuronidase activity in the granulocytes seemed to be low only in case 1. As for acid phosphatase, there were some evidences of a nonlysosomal localization of acid $p$-nitrophenyl phosphate phosphatase (2); our result is compatible with that of previously reports assayed with $\beta$ glycerophosphate. These findings suggest that lysosomal acid phosphatase in CHS granulocytes is normal.

One of the most obvious finding in this study was the markedly decreased activities of $\alpha$-mannosidase, $\alpha$-galactosidase, and $\alpha$-fucosidase in CHS granulocytes. The enzyme inhibitor in the CHS lysates could not be found by the mixing experiments with normal ones. We reported previously the characteristic profiles of lysosomal enzyme content in normal granulocytes, lymphocytes, and lymphocytes subpopulations $(16,17)$. It is an interesting coincidence that these three enzymes, out of examined nine enzymes, provided the characteristic enzyme profile of normal granulocytes. Desnick et al. (7) revealed that a patient with $\alpha$-mannosidase deficiency showed impaired chemotaxis and phagocytosis of bacteria and decreased response of lymphocyte to mitogens. Paus and Steen (12) reported that $\alpha$-mannosidase itself acts as a mitogen in a manner similar to that of mitogenic lectins. These findings suggest that certain acid hydrolases acting on glycosides seem to have a relation to leukocyte functions and that some acid glycosidase-deficient state in granulocytes may account for their functional abnormality, such as shown in this study and in $\alpha$-mannosidosis, although the precise relationship is not known.

In the CHS lymphocytes, the activities of $\beta$-glucuronidase and $\alpha$-mannosidase were low. However, at present, we have no evidence to suspect that any special enzyme deficiency account for the functional abnormality in CHS lymphocytes.
It is also noteworthy that the patients described here were in the accelerated phase. It may be that the reduction of some lysosomal enzyme activities is due to the accelerated phase or that the decrease in the enzyme activities cause this phase. We cannot differentiate between these two possibilities. The CHS homologous trait in animals do not seem to have a tendency to develop the accelerated phase (20). We have not known about the factors which let CHS patients into the accelerated phase. The interesting study by Allison and Paton (1) on the relationship of lysosomes and lysosomal enzymes to chromosomal abnormalities and carcinogenesis are of special significance in a consideration of the pathogenesis of the accelerated phase in CHS. They have concluded that one of the mechanisms of carcinogenesis might be abnormal redistribution of lysosomal enzymes by carcinogens, such as virus or chemicals, resulting in a genetic alteration of the affected cell, of which the phenotypic expression is malignancy. The CHS patients have above-mentioned factors, such as abnormal lysosomes and increased susceptibility to infection. However, there remain too many unanswered questions in this syndrome.

There have been few reports concerning the CHS heterozygous state. Danes and Bearn (6) reported that skin fibroblasts from CHS heterozygotes grown in cell culture contained abnormal cytoplasmic inclusions. Blume et al. (3) described abnormally large granules in cultured heterozygous lymphoid cells but these were not as common or as marked as those in the homozygote cells. A reliable tool for detecting a CHS heterozygote has not been yet reported. As far as we know, this is the first report of two pairs of parents (obligate heterozygotes) who have shared the same abnormality of lysosomal enzyme levels in their granulocytes. In this study, we could not find other abnormality in heterozygotes such as clinical states and prepared granulocytes of 
which purities were above $98 \%$ containing $91 \pm 3 \%$ of neutrophils. The enzyme activator in their granulocytes could not be found. The brother of case 1 also had the enzyme abnormality in his granulocytes similar to the obligate heterozygotes. Thus, he may be a carrier of the abnormal gene. This study on the family members suggests, at least, that carriers of this inherited disease could be detected by examination of the altered enzyme activities in granulocytes, such as acid phosphatase, aryl sulphatase, $\mathrm{N}$ acetyl- $\beta$-glucosaminidase, and $\beta$-glucuronidase, all of which showed significantly elevated activities. However, the reasons why the altered enzyme levels occurs in this syndrome and why there is a difference in variety of altered enzyme levels in granulocytes between CHS homozygotes and heterozygotes are not known. The data in this study are insufficient to explain these questions. Further studies are needed to clarify the primary defect and the pathogenesis of this syndrome.

\section{REFERENCES AND NOTES}

1. Allison, A. C and Paton, G. R: Chromosome damage in human diploid cells following activation of lysosomal enzymes. Nature (Lond.). 207: 1170 (1965).

2. Beaufay, H.: Methods for the isolation of lysosomes. In: J. T. Dingle: Lysosomes--a laboratory handbook. pp. 1-45 (North-Holland Publishing Co. Amsterdam. 1972).

3. Blume, R. S. Glade, P. R., Gralnick, H. R. Chessin, L. N., Haase, A. T., and Wolff. S. M.: The Chediak-Higashi syndrome: continuous suspension cultures derived from peripheral blood. Blood. 33: 832 (1969).

4. Blume, R. S., and Wolff. S. M.: The Chediak-Higashi syndrome; Studies in four patients and a review of the literature. Medicine, 51:247 (1972).

5. Boyum. A.: Separation of leukocytes from blood and bone marrow. Scand. J. Clin. Lab. Invest., 21 (Suppl. 97): (1968).

6. Danes, B. S.. and Bearn. A. G.: Cell culture and the Chediak-Higashi syndrome. Lancet. 2: 65 (1967).

7. Desnick, R. J.. Sharp. H. L., Grabowski, G. A.. Brunning, R. D., Quie. P. G. Sung, J. H., Gorlin, R. J., and Ikonne, J. U.: Mannosidosis: clinical, morphologic, immunologic and biochemical studies. Pediatr. Res., 10: 985 (1976).

8. Hinegardner, R. T.: An improved fluorometric assay for DNA. Anal. Biochem. 39: 197 (1971).

9. Kimball, H. R.. Ford. G. H., and Wolff, S. M.: Lysosomal enzymes in normal and Chediak-Higashi blood leukocytes. J. Lab. Clin. Med.. 86: 616 (1975)

10. Oliver. J. M., and Zurier, R. B.: Correction of characteristic abnormalities of microtubule function and granule morphology in Chediak-Higashi syndrome with cholinergic agonists. Studies in vitro in man and in vivo in the beige mouse. J. Clin. Invest., 57: 1239 (1976).

11. Padgett. G. A.: Neutrophilic function in animals with the Chediak-Higashi syndrome. Blood, 29: 906 (1967).

12. Paus, E., and Steen, H. B.: Mitogenic effect of $\alpha$-mannosidase on lymphocytes. Nature (Lond.), 272: 452 (1978).

13. Rausch. P. G.. Pryzwansky, K. B., and Spitznagel., J. K.: Immunocytochemical identification of azurophilic and specific granule markers in the giant granules of Chediak-Higashi neutrophils. N. Engl. J. Med., 298: 693 (1978).

14. Root. R. K.. Rosenthal, A. S., and Balestra. D. J.: Abnormal bactericidal, metabolic, and lysosomal functions of Chediak-Higashi syndrome leukocytes. J. Clin. Invest., 51: 649 (1972).

15. Stossel, T. P., Root, R. K., and Vaughan, M.: Phagocytosis in chronic granulomatous disease and the Chediak-Higashi syndrome. N. Engl. J. Med.. 286: 120 (1972).

16. Tanaka. T.: The different composition of eight lysosomal enzymes in human peripheral lymphocytes and granulocytes. Hiroshima J. Med. Sci., 27: 253 (1978).

17. Tanaka, T.: Biochemical activities of nine lysosomal enzymes in $T$ and non-T lymphocytes. FEBS Lett., 104: 161 (1979).

18. Tebbi, K.: Purification of lymphocytes. Lancet, I: 1392 (1973).

19. White. J. G.: Chediak-Higashi syndrome: a possible lysosomal disease. Blood. 28: $143(1966)$.

20. Windhorst, D. B., and Padgett. G.: The Chediak-Higashi syndrome and the homologous trait in animals. J. Invest. Dermatol.. 60: 529 (1973).

21. Wolff, S. M., Dale, D. C.. Clark, R. A., Root, R. K., and Kimball, H. R. The Chediak-Higashi syndrome: studies of host defences. Ann. Intern. Med., 76: 293 (1972).

22. Yam, L. T., Li, C. Y.. and Crosby. W. H.: Cytochemical identification of monocytes and granulocytes. Am. J. Clin. Pathol., 55: 283 (1971).

23. The author is grateful to Professor Tomofusa Usui for helpful criticism and discussion and thanks Drs. M. Hozumi, T. Matsunaga (Himeji Red Cross Hospital), and K. Mizoguchi, Y. Okubo (Osaka Red Cross Hospital) for their cooperation of this study.

24. Requests for reprints should be addressed to: Dr. T. Tanaka. Deparment of Pediatrics, Hiroshima University School of Medicine, 1-2-3, Kasumi-Cho, Hiroshima, 734. Japan.

25. This research was supported by Research Grant 144052 from the Ministry of Education of Japan.

26. Received for publication April 30, 1979

27. Accepted for publication November 6, 1979. 